Journal of Applied Veterinary Sciences, 6 (4): 39 -45 (October, 2021).

ISSN: Online: 2090-3308, Print: 1687-4072

Journal homepage : https://javs.journals.ekb.eg

\title{
Virulence Traits and Antimicrobial Sensitivity Testing of Untyped Mycoplasma species Recovered From Sheep and Goats in Egypt
}

\author{
Mona, M. Osman', Manal Abu Elmakarem Mohamed ${ }^{1}$, Heba, N. Deif ${ }^{2^{*}}$, and Kamelia, M. Osman ${ }^{2}$ \\ ${ }^{1}$ Mycoplasma Department, Animal Health Research Institute, ARC., Giza, Egypt. \\ ${ }^{2}$ Microbiology Department, Faculty of Veterinary Medicine, Cairo University, Giza, Egypt. \\ *Corresponding Author, Heba N. Deif, E-Mail: naim_heba@yahoo.com
}

\begin{abstract}
Many Mycoplasma species are involved in caprine and ovine pneumonia all over the world causing serious economic losses. These species have been reported to cause pneumonia, mastitis, arthritis, conjunctivitis and genital infection. The objective of the present study was to detect Mycoplasma species in the respiratory system of sheep and goats. So, a total of 400 samples (250 from sheep and 150 from goat) were examined bacteriologically, biochemically, by PCR, sequencing, in addition to the antibiotic susceptibility profiles screening. Only 13 isolates could be identified as Mycoplasma species. One of these sequences was submitted to the Genbank taking the accession number MK910041; Mycoplasma species 'ovine/caprine serogroup 11'. Only 7 isolates were weak biofilm producers and the other 6 isolates were non biofilm producers; 8 isolates were positive for the catalase test and 5 were negative. $\mathrm{H}_{2} \mathrm{~S}$ production was recorded in 10 isolates; haemolysis was detected in only 6 isolates. In addition, the minimum inhibitory concentrations (MICs) for seven antimicrobial agents, including danofloxacin, tulathromycin, tylosin, streptomycin, lincomycin, florfenicol and oxytetracycline, were determined. All the isolates (100\%) were sensitive to tulathromycin and tylosin, streptomycin and oxytetracycline; $38.5 \%$ were sensitive to danofloxacin, $69.2 \%$ were sensitive to florfenicol, while $69.2 \%$ of isolates were resistant to lincomycin. As all the isolates were recovered from apparently healthy and clinically diseased animals and identified as untyped Mycoplasma species, more investigations will be done to identify these isolates and discover their roles in infection.
\end{abstract}

Original Article:

DOI:https://dx.doi.org/10.21608/javs.2 $\underline{021.88356 .1095}$

Received :31 July, 2021.

Accepted:04 September, 2021.

Published in October, 2021.

This is an open access article under the term o Creative Commons Attribution 4.0 (CCInternational License . To view a copy of license, visit:

http://creativecommons.org/licenses/by/4.0/

J. Appl. Vet. Sci., 6(4): $39-45$.

Keywords: Biofilm-formation, Goat, Sheep, Untyped-Mycoplasmaspecies, Virulence-genes.

\section{INTRODUCTION}

Mycoplasmas are the smallest, self-replicating bacteria that lack cell walls; therefore, they have intrinsic resistance to penicillin and B- lactam antibiotics. They affect all animal species such as chicken flocks (El-Ashram et al., 2021), sheep, goats (Adehana et al., 2006), and human beings, causing serious pathological conditions including respiratory problems and mastitis, arthritis and genital disorders. Mycoplasma species have been reported as a cause of pneumonia, mastitis, arthritis, conjunctivitis and genital infection. Sheep are important household animals and play a major role in the economic status of farmers in Egypt like many other developing countries. They constitute an important component of Egypt's food security plan. The most pathogenic Mycoplasma species affecting sheep and goats is Mycoplasma capricolum subsp. capripneumoniae (Mccp); the main cause of contagious caprine pleuropneumonia (CCPP) OIE (2017) List disease; and M. agalactiae; the cause of classical contagious agalactia (CA).

Other Mycoplasma species have been isolated from sheep and goats suffering from respiratory problems and apparently healthy animals (M. arginini, M. ovipneumoniae, and M. mycoides subsp. capri and M. capricolum subsp. capricolum (Nicholas et al., 2008). Respiratory affection in sheep is a major multifactorial problem causing significant economic losses; many bacterial and viral species can cause it in addition to Mycoplasma species. The most commonly recorded Mycoplasma species with respiratory infection worldwide is $M$. arginini and $M$. ovipneumoniae (Azizi et al., 2011; Chinedu et al., 2014; Abdel Halium et al., 2019). The infection may 
be caused by a combination of these species, especially for young lambs (Niang et al., 1999).

M. ovipneumoniae is a serious and highly infectious pathogen causing lethal pneumonia in sheep and goats which appear in all ages, especially in lambs (Besser et al., 2013). Clinical observations showed difficult breathing with dyspnea, followed by death in newborn kids and those up to 2 months of age. In young lambs, it can be associated with a severe paroxysmal cough that predisposes to rectal prolapses, termed coughing syndrome. Between flocks, this disease is chronic and lasts for several weeks, with variable morbidity and mortality rates (Nicholas et al., 2008). In many reports, the number of isolated Mycoplasma species was not identified by the known species-specific primers (Kılıc et al., 2013).

The present study was designed for isolation and molecular characterization of Mycoplasma species affecting sheep and goats, detection of biofilm formation and evaluation of the antimicrobial susceptibility of the obtained isolates by MIC test.

\section{MATERIIALS AND METHODS}

\section{Sample collection and preparation:}

A total of 400 sheep and goats samples were randomly collected between December 2017 till May 2018 from El-Basatin slaughterhouse in Cairo, Egypt. Pneumonic lung samples $(n=240)$, referring to those showing various degrees of congestion, fibrin deposition, and/ or pleural adhesion to the lung, were collected then transported to the Microbiology laboratory- Faculty of Veterinary Medicine, Cairo University in a special icefilled container. A hot spatula seared the outer surface of the lung sample before cutting the lung's inner surface to avoid any contamination. Very small parts of the lung were cultured on PPLO broth and incubated at $37^{\circ} \mathrm{C}$ for $24-48$ hours and sub-cultured twice to minimize the contamination, then were cultured on PPLO agar medium by the running drop technique, incubated at $37^{\circ} \mathrm{C}$, with $5-10 \% \mathrm{CO}_{2}$ for $7-14$ days. Mild turbidity in a liquid medium and the appearance of fried egg colonies on the solid media indicate suspected Mollicutes growth. Nasal swabs $(n=160)$ collected from apparently healthy animals were taken by sterile cotton swabs deeply embedded in the nostrils, then kept in an icebox and submitted to the laboratory. Samples were then processed as lung samples but incubated for 7-21 days and examined regularly.

Digitonin sensitivity test for differentiation between Mycoplasma and Acholeplasma: using a filter paper disc impregnated in $0.2 \mathrm{ml}$ of $1.5 \%$ (w/v) ethanol solution of digitonin. Mycoplasma species are digitonin sensitive, while Acholeplasma is resistant to digitonin (Freundt, 1973). Further identification for the isolates using biochemical tests as glucose fermentation and arginine deamination tests were done (Erno, 1987).

\section{Phenotypic virulence traits of Mycoplasma species isolates:}

Four assays were used for demonstration of the phenotypic virulence traits of Mycoplasma isolates using: semi-quantitative analysis of biofilm formation using crystal violet staining by measuring the absorbance $(620 \mathrm{~nm})$ of $100 \mathrm{ml}$ of the solubilized crystal violet in a microtiter plate according to McAuliffe et al., (2006), hemolytic and haemoxidative activity of the isolates according to Großhennig $\boldsymbol{e t}$ al., (2016), catalase activity assay according to Pritchard and Mitchell, (2015), hydrogen sulfide production by the isolates using lead acetate detection strips according to Shatalin et al., (2011).

\section{Molecular identification:}

\section{Preparation of samples for DNA extraction:}

Five $\mathrm{ml}$ of 24 hours broth culture of each isolate was centrifuged at $8000 \mathrm{rpm}$ (JOUAN) for 15 min in a $1.5 \mathrm{ml}$ microtube. The obtained pellets were washed three times with Phosphate-Buffered Saline $\mathrm{pH}$ 7.4 , heated at $100^{\circ} \mathrm{C}$ for $10 \mathrm{~min}$ in a heat block (TECHNE DB-3A) followed by freezing for $10 \mathrm{~min}$, finally, centrifuged for $5 \mathrm{~min}$. Then, the supernatant containing chromosomal DNA was collected and stored at $-20^{\circ} \mathrm{C}$ until used.

\section{Mycoplasma species identification:}

The isolates were confirmed as mycoplasmas by PCR amplification using Mycoplasma genusspecific primer according to Van Kuppeveld et al., (1992) using the following primer sequences [Gpo 3 (5'-ACTCCTACGGGAGGCAGCAGTA-3') and Mgso (5'-TGCACCATCTGTCACTCTGTTAACCTC-3')

giving a final amplification product at $264 \mathrm{bp}$. PCR reaction was performed in a total of $50 \mu \mathrm{l}$ reaction volume consisting of $5 \mu \mathrm{l}$ of $50 \mathrm{ng}$ of genomic DNA,1 $\mu 1$ of $50 \mathrm{pM}$ of each primer, and 25ul PCR master mix (Thermo fisher scientific), $18 \mu \mathrm{l}$ of DNase- RNase- free, deionized water. Thermal conditions in (GTC96S cleaver scientific) one cycle of denaturation step at $94^{\circ} \mathrm{C}$ for $5 \mathrm{~min}, 40$ cycles of denaturation at $94^{\circ} \mathrm{C}$ for $45 \mathrm{~s}$, annealing at $55^{\circ} \mathrm{C}$ for the $60 \mathrm{~s}$ and extension at $72^{\circ} \mathrm{C}$ for $60 \mathrm{~s}$, and a final extension step at $72^{\circ} \mathrm{C}$ for 10 min. The amplified products were examined in UV transilluminator after electrophoresis in $1.5 \%$ agarose gel containing $0.005 \%$ ethidium bromide in $1 \times$ Tris/borate/EDTA buffer at $7 \mathrm{~V} / \mathrm{cm}$. The amplified PCR products were sequenced (AHRI, EGYPT). One of these sequences was submitted to NCBI-Genbank taking the accession number: MK910041.1. The assembled DNA sequence was subjected to BLAST analysis. After aligning the sequences using the CLUSTAL W algorithm method, phylogenetic analysis 
was done using the neighbor-joining method using MEGA 6.0 software (Fig. 1).

\section{Antimicrobial sensitivity testing:}

It was performed and the number of colourchanging units (CCU) was determined by the MIC method (Felde et al., 2018). The selected antimicrobial agents are those frequently used in Egypt: Quinolones: danofloxacin; Phenicol: florfenicol; Macrolides: tylosin and tulathromycin; Aminoglycosides: streptomycin; Lincosamide: lincomycin; Tetracycline: oxytetracycline. All the strains were tested in duplicates and all the plates contained a duplicate of the type strain (NCTC 10110) as a quality control. The results were interpreted according to TerLaak $\boldsymbol{e t} \boldsymbol{a l}$., (1993); Hirose et al. (2003); and CLSI (2011).

\section{RESULTS}

Out of 400 samples from sheep and goats, only $13(3.25 \%)$ were identified as Mycoplasma species represented as 2 isolates (1\%) from sheep lung samples, 3 isolates $(6 \%)$ from sheep nasal swabs, 3 isolates $(7.5 \%)$ from goat lung samples and 5 isolates $(4.5 \%)$ from goat nasal swabs. Therefore, the incidence of Mycoplasma species isolation from goats $5.3 \%$ was higher than that from sheep 2\% (Table, 1).

Table1: Results of Mycoplasma species isolation from the examined samples

\begin{tabular}{|c|c|c|c|}
\hline \multirow[t]{2}{*}{ Type of sample } & \multirow{2}{*}{$\begin{array}{c}\text { No of } \\
\text { examined } \\
\text { samples }\end{array}$} & \multicolumn{2}{|c|}{$\begin{array}{l}\text { Mycoplasma } \\
\text { species }\end{array}$} \\
\hline & & No & $\%$ \\
\hline Sheep (lung tissue) & 200 & 2 & 1 \\
\hline Sheep (nasal swab) & 50 & 3 & 6 \\
\hline Total Sheep samples & 250 & 5 & 2 \\
\hline Goat (lung tissue) & 40 & 3 & 7.5 \\
\hline Goat (nasal swab) & 110 & 5 & 4.5 \\
\hline Total goat samples & 150 & 8 & 5.3 \\
\hline Total samples & 400 & 13 & 3.25 \\
\hline
\end{tabular}

Biochemical testing of the isolates showed that they were negative for arginine hydrolysis but were positive for both digitonin and glucose fermentation tests. Virulence characteristics revealed that 7 isolates $(53.8 \%)$ were biofilm producers while $6(46.2 \%)$ were non biofilm producers. Catalase activity was detected in 8 isolates $(61.5 \%)$ and was absent in 5 isolates $(38.5 \%)$. We observed that 6 isolates $(46.2 \%)$ were hemolytic and the other isolates (53.8) were nonhaemolytic. $\mathrm{H}_{2} \mathrm{~S}$ was detected in 10 isolates (76.9\%) and was not revealed in 3 isolates $(23.1 \%$ ) (Table 2).

All the isolates could produce amplified DNA products with the suspected amplicon size (photo. 1). One of the sequence results of Mycoplasma isolates was sent to the Genbank taking the accession number "MK910041.1".

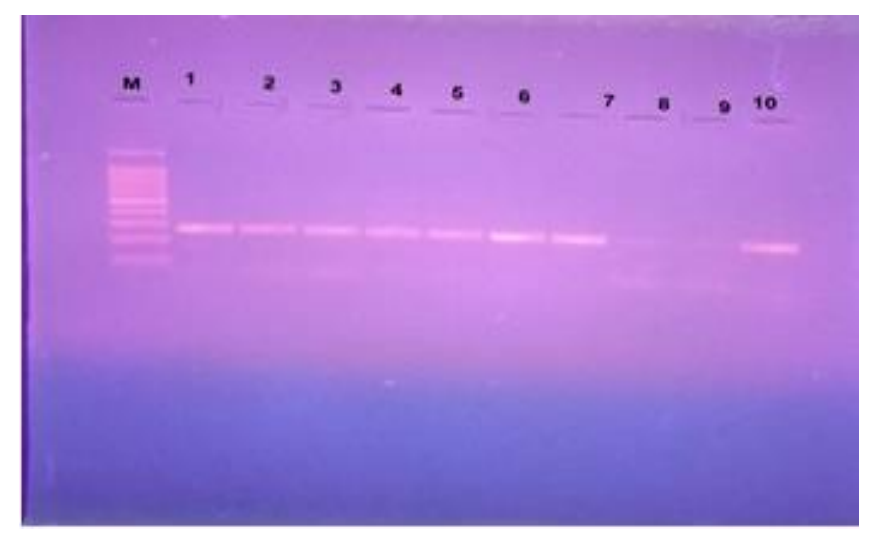

Photo 1: Electrophoresis of PCR products of ten tested Mycoplasma isolates showing amplified products at $264 \mathrm{bp}$ represented as Lane M: molecular marker (100-1500bp), Lanes (1-10) representative positive samples.

Table 2: Virulence characteristics and biochemical activity of the isolates

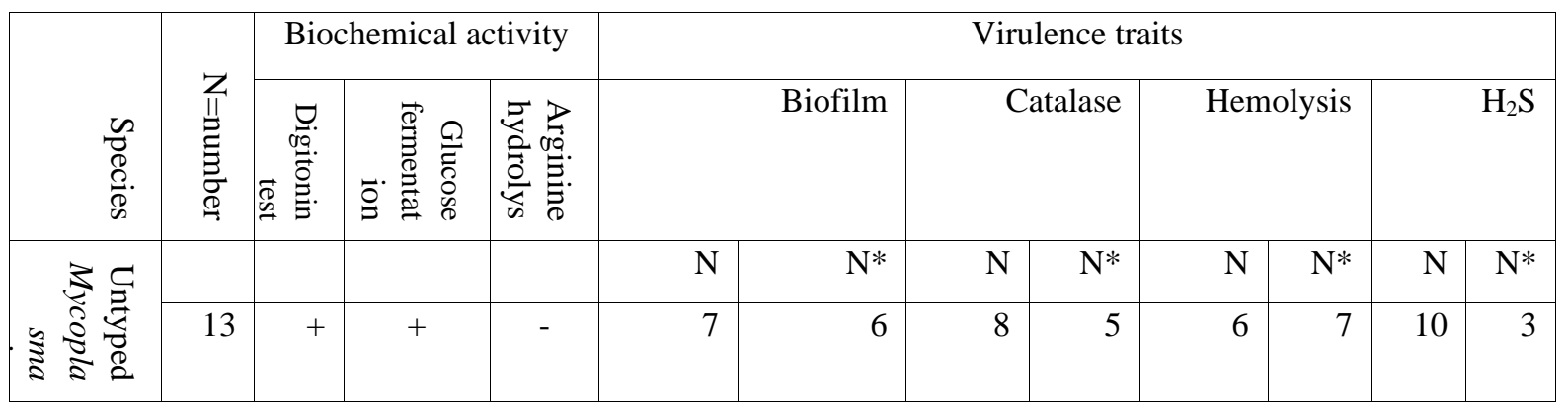

$\mathrm{N}$ : number of positive samples

$\mathrm{N}^{*}$ : number of negative samples 
Virulence traits and antimicrobial sensitivity testing of .......

Table 3: Antibiotic susceptibility testing results of sheep Mycoplasma isolates

\begin{tabular}{|c|c|c|c|c|c|c|}
\hline \multirow{2}{*}{ Antimicrobial agent } & \multicolumn{7}{|c|}{ Mycoplasma isolates (n=13) } \\
\cline { 2 - 7 } & \multicolumn{2}{|c|}{$\mathrm{S}$} & \multicolumn{2}{c|}{$\mathrm{I}$} & \multicolumn{3}{c|}{$\mathrm{R}$} \\
\cline { 2 - 7 } & No & $\%$ & No & $\%$ & No & $\%$ \\
\hline Danofloxacin & 5 & 38.5 & 5 & 38.5 & 3 & 23 \\
\hline Tulathromycin & 13 & 100 & 0 & 0 & 0 & 0 \\
\hline Tylosin & 13 & 100 & 0 & 0 & 0 & 0 \\
\hline Streptomycin & 13 & 100 & 0 & 0 & 0 & 0 \\
\hline Lincomycin & 4 & 30.8 & 0 & 0 & 9 & 69.2 \\
\hline Florfenicol & 9 & 69.2 & 4 & 30.8 & 0 & 0 \\
\hline Oxytetracycline & 13 & 100 & 0 & 0 & 0 & 0 \\
\hline
\end{tabular}

R: resistant, I: intermediate, S: sensitive $\quad \%$ was calculated to the total examined Mycoplasma species.

Table 4: Antimicrobial sensitivity testing, virulence characteristics of all Mycoplasma species isolated from sheep and goat:

\begin{tabular}{|c|c|c|c|c|c|c|c|c|c|c|c|c|c|}
\hline \multirow[t]{2}{*}{ 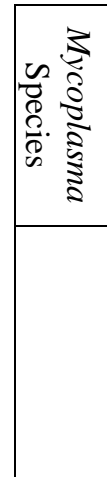 } & \multirow[t]{2}{*}{ 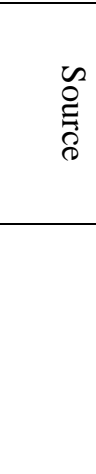 } & \multirow[t]{2}{*}{ 胥. } & \multicolumn{4}{|c|}{ 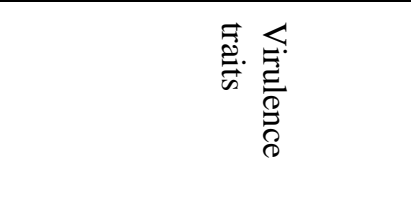 } & \multicolumn{7}{|c|}{ 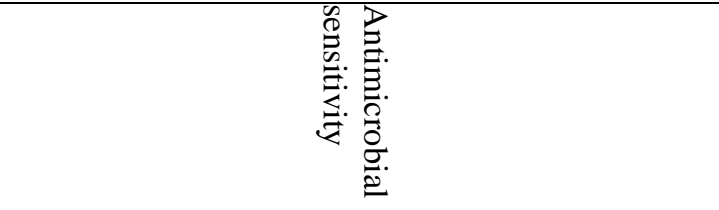 } \\
\hline & & & $\begin{array}{l}\text { 品. } \\
\text { : } \\
\text { : }\end{array}$ & 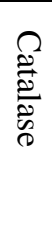 & 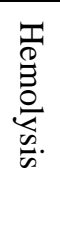 & $\underset{\sim}{\mathbb{U}}$ & 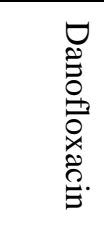 & 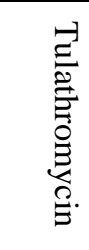 & $\begin{array}{l}\vec{\vdots} \\
0 \\
0 \\
0 .\end{array}$ & 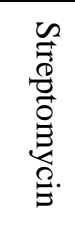 & 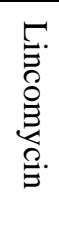 & 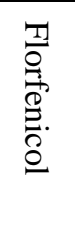 & 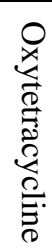 \\
\hline 1 & lung & sheep & 0.593 & + & + & - & 0.125 & 1 & 1 & 1 & 2 & 2 & 1 \\
\hline 2 & lung & Goat & 0.328 & - & - & + & 1 & 2 & 2 & 2 & 2 & 2 & 2 \\
\hline 3 & lung & sheep & 0.268 & - & + & + & 0.5 & 2 & 1 & 1 & 1 & 4 & 4 \\
\hline 4 & $\begin{array}{l}\text { Nasal } \\
\text { swab }\end{array}$ & sheep & 0.370 & + & - & + & 0.5 & 1 & 0.5 & 2 & 2 & 2 & 2 \\
\hline 5 & $\begin{array}{l}\text { Nasal } \\
\text { swab }\end{array}$ & sheep & 0.255 & + & + & + & 1 & 1 & 1 & 2 & 1 & 2 & 4 \\
\hline 6 & $\begin{array}{l}\text { Nasal } \\
\text { swab }\end{array}$ & Sheep & 0.350 & + & + & + & 2 & 1 & 2 & 2 & 2 & 2 & 4 \\
\hline 7 & Lung & Goat & 0.312 & + & - & + & 2 & 0.5 & 2 & 2 & 4 & 4 & 4 \\
\hline 8 & Lung & Goat & 0.296 & - & + & + & 1 & 0.5 & 2 & 2 & 4 & 2 & 2 \\
\hline 9 & $\begin{array}{l}\text { Nasal } \\
\text { swab }\end{array}$ & Goat & 0.414 & + & - & + & 2 & 2 & 0.25 & 1 & 4 & 0.5 & 2 \\
\hline 10 & $\begin{array}{l}\text { Nasal } \\
\text { swab }\end{array}$ & Goat & 0.221 & - & - & - & 1 & 0.125 & 1 & 1 & 1 & 4 & 4 \\
\hline 11 & $\begin{array}{l}\text { Nasal } \\
\text { swab }\end{array}$ & Goat & 0.300 & + & - & + & 0.5 & 1 & 2 & 1 & 1 & 4 & 2 \\
\hline 12 & $\begin{array}{l}\begin{array}{l}\text { Nasal } \\
\text { swab }\end{array} \\
\end{array}$ & Goat & 0.236 & - & - & + & 1 & 1 & 2 & 0.25 & 2 & 2 & 2 \\
\hline 13 & $\begin{array}{l}\text { Nasal } \\
\text { swab }\end{array}$ & Goat & 0.211 & + & + & - & 0.5 & 0.25 & 2 & 2 & 4 & 2 & 4 \\
\hline
\end{tabular}

Mycoplasma species 2 carries the accession number "MK910041". 
By testing the sequence result (MK910041.1) against the other sequences on Genbank, it showed 100\% identity to the strains: MK615054.1, LC158833.1, NR_113690.1, HQ661809.1, AY121109.1, AY121108.1, AY121107.1, AY121106.1, AY121105.1, AY121104.1, AY121103.1, and AY12109.1, but showed 99.62 similarity with the strains: AY121100.1, MK789488.1, MK789480.1, MK789479.1, MK789478.1 and MK789477.1.

The evolutionary history was inferred using the Neighbor-Joining method. The bootstrap consensus tree inferred from 100 replicates is taken to represent the evolutionary history of the taxa analyzed. Branches corresponding to partitions reproduced in less than $50 \%$ bootstrap replicates are collapsed. The evolutionary distances were computed using the Jukes-Cantor method and are in the units of the number of base substitutions per site. The analysis involved 19 nucleotide sequences. Codon positions included were $1 \mathrm{st}+2 \mathrm{nd}+3 \mathrm{rd}+$ Noncoding. All positions with less than $95 \%$ site coverage were eliminated. That is, fewer than $5 \%$ alignment gaps, missing data, and ambiguous bases were allowed at any position. There were a total of 263 positions in the final dataset. Evolutionary analyses were conducted in MEGA6 (Tamura et al., 2013) (Fig. 1).

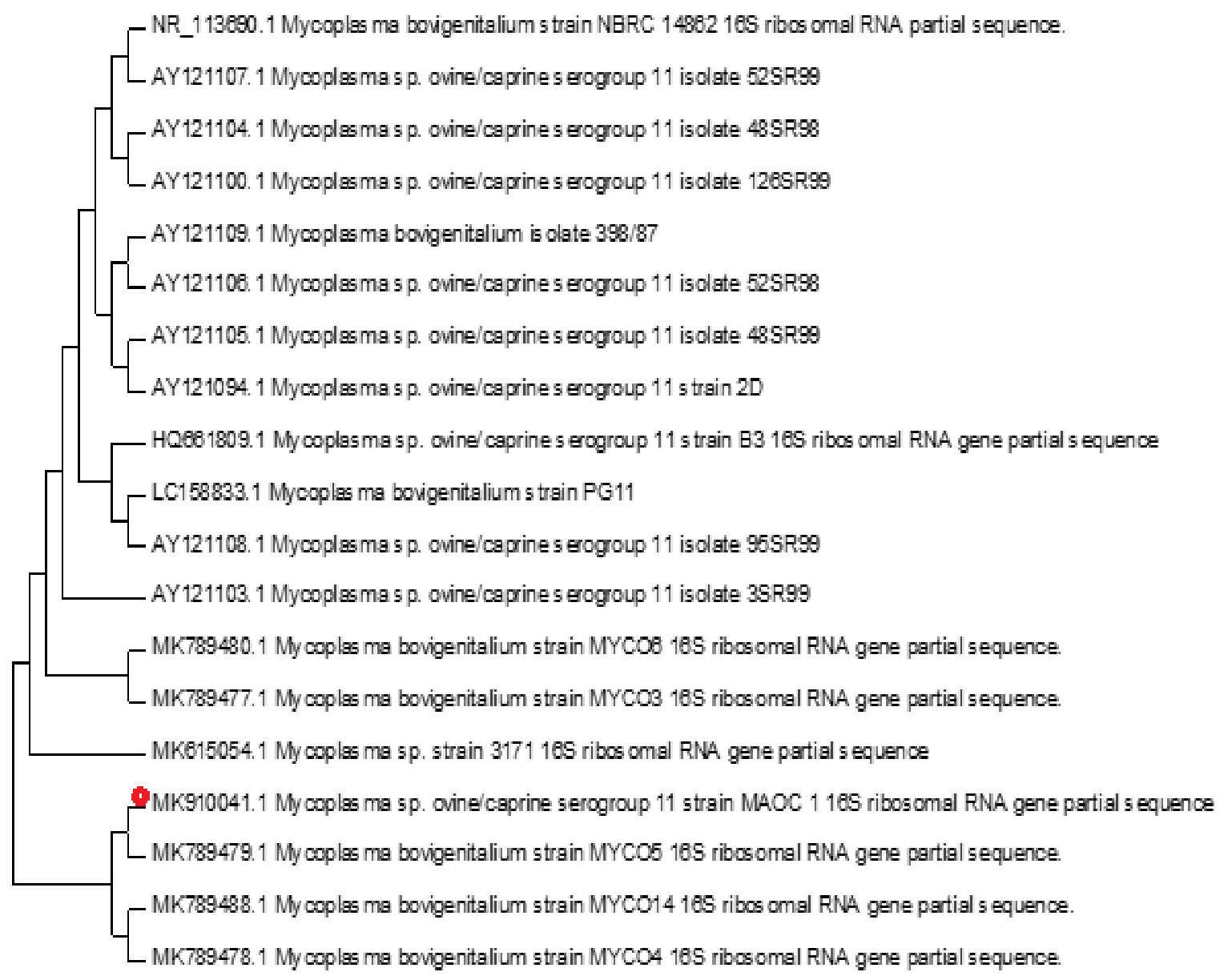

Fig.1: Evolutionary relationships of taxa

\section{DISCUSSION}

Mycoplasmas are highly fastidious, difficult to be cultured and slow-growing bacteria. Many species are veterinary pathogens causing respiratory infection, mastitis, conjunctivitis, arthritis, and occasionally abortion. The World Association for Animal Health (OIE, 2017) listed four important diseases of most livestock because of their socio-economic impacts. They comprise Contagious Bovine Pleuro-Pneumonia (CBPP), Contagious Agalactia, Contagious Caprine Pleuro-Pneumonia (CCPP) and Avian Mycoplasmosis.
Others include enzootic pneumonia, costly worldwide disease of pigs, bovine mycoplasmosis, which is characterized by respiratory distress, mastitis and arthritis, and community-acquired atypical pneumonia in humans. New Mycoplasma disease outbreaks in desert tortoises and bighorn sheep have attracted the attention for the future of these endangered species (Nicholas, 2017).

For sheep and goats, mycoplasmal pneumonia has been associated with $M$. ovipneumoniae, M. capricolum subsp. capricolum, $M$. 
mycoides subsp. mycoides LC and M. arginini (Ikheloa et al., 2004). M. ovipneumoniae is the most commonly isolated Mycoplasma from the upper respiratory tract of normal sheep and can be significant in respiratory disease in both sheep and goats (Grand et al., 2004). During stressful times, a subclinical infection may predispose sheep to atypical pneumonia with paroxysmal coughing (Niang et al., 1999). The infection is sometimes associated with $M$. haemolytica, Parainfluenza-3 virus or $M$. arginini. In the present study, the isolation rate of Mycoplasma species was $3.25 \%$, which agrees with that mentioned by Maksimović et al. (2013).

\section{Mycoplasma isolation rate:}

was $3.4 \%$ of the examined samples. Also, this result was near to that recorded by Kılic et al. (2013) who studied Mycoplasma in the lungs of sheep and lambs with pneumonia with an incidence of $8.33 \%$. Abdel Halium, et al., (2019) identified undifferentiated Mycoplasma species with an incidence of $41.6 \%$ from total positive Mycoplasma isolates while it was $2.98 \%$ from the total collected samples.

Concerning the haemolytic activity of Mycoplasma species recovered from sheep and goat, 6 isolates $(46.2 \%)$ were hemolytic and 7 isolates $(53.8 \%)$ were non-haemolytic and that agrees with Cole $\boldsymbol{e t}$ al., (1968) who tested the haemolytic activity of various animal and human Mycoplasma on erythrocytes from various sources (sheep- rabbit- chicken- guinea pigduck). Also, these results agree with Großhennig et al., (2016) who studied this activity in more detail; he incubated M. pneumoniae M129 on MP agar plates and overlaid the sheep blood agar with the growing bacteria.

The submitted sequence to the Genbank was identified as M. ovine/caprine serogroup 11. This is the first time for isolation of this bacterial species from the goat respiratory tract. But, it matches with that previously isolated from the lung of goats by DaMassa et al. (1992), known as Mycoplasma 2D that usually causes genital disorders in ruminants. Little information is known about the pathogenicity and epidemiology of this strain.

In recent literature, $M$. ovine/caprine serogroup 11 was classified as $M$. bovigenitalium (Nicholas et al., 2008) documented that the comparison of $16 \mathrm{~s}$ and $23 \mathrm{~s}$ rRNA sequences of $10 \mathrm{M}$. ovine/caprine serogroup 11 and 6 strains of $M$. bovigenitalium showed that they shared 98-100\% similarity between all the tested strains but only 8695\% to other Mycoplasma species.

\section{CONCLUSION}

In conclusion, not only the identified Mycoplasma species but also the untyped ones can be isolated from apparently healthy as well as clinically diseased sheep and goats. Due to its hazardous role in infection, more studies about their pathogenicity and genetic characters are needed.

\section{Declaration of Conflicting Interests}

The authors revealed that there was no potential conflicts of interest.

\section{REFERENCES}

ABDEL HALIUM, M. M., SALIB, F. A., MAROUF, S. A., and ABDEL MASSIEH, E. S., 2019. Isolation and molecular characterization of Mycoplasma spp. in sheep and goats in Egypt, Veterinary World. 12(5): 664-670. doi: 10.14202/vetworld.2019.664-670.

ADEHANA, R. K., AJUWAPE, A. T. P., ADETOSOYE, A. I., and ALAKA, O. O., 2006. Characterization of mycoplasmas isolated from pneumonic lungs of sheep and goats. Small Rumin. Res., 63: 44-49.

AZIZI, S., TAJBAKHSH, E., REZAII, A., NEKOUEI, SH., and NAMJOO, A. R., 2011. The role of Mycoplasma ovipneumoniae and Mycoplasma arginini in pneumonic lungs of slaughtered sheep Revue Méd. Vét. 162(6): 310-315. Electronic ISSN 0035-1555.

BESSER, T. E., CASSIRER, E. F., HIGHLAND, M. A., WOLFF, P., JUSTICE-ALLEN, A., MANSFIELD, K., DAVIS, M. A., and FOREYT, W., 2013. Bighorn sheep pneumonia: sorting out the cause of a polymicrobial disease. Prev. Vet. Med. 108: 85e93. DOI: $10.1016 /$ j.prevetmed.2012.11.018

CHINEDU, A. A., and ROGER D. A., and KENNEDY F. Ch., and Stephen I. O., 2014. Studies into the prevalence of Mycoplasma species in small ruminants in Benue State, North-central Nigeria. Trop Anim Health Prod. 46:1087-1092. PMID: 24828562. DOI: 10.1007/s11250-014-0613-6.

COLE, B. C., WARD, J. R., and MARTIN, C. H., 1968. Hemolysin and peroxide activity of Mycoplasma species. J Bacteriol. 95: 2022-2030. PMID: 4876125; PMCID: PMC315129.

DaMASSA, A. J., WAKENELL, P. S., and BROOKS, D. L., 1992. Mycoplasmas of sheep and goat. J. Vet. Diagn. Invest. 4:101-113. DOI: 10.1177/104063879200400126.

EL-ASHRAM, S., HASHAD, M. E., ABDEL-ALIM, G. A., ABDELHAMID, T., and DEIF, H. N., 2021. Seroprevalence of mycoplasmosis in broiler, layer, and native chickens in Giza, Egypt. PLoS One. 12:16(7):e0254220.

doi: 10.1371/journal.pone.0254220. PMID: 34252126. https://doi.org/10.1371/JOURNAL.PONE.0254220.

ERNO, H. 1987. Mycoplasmosis of ruminants: a general introduction. Revue Scientifique et Technique, Office International des Epizooties. 6: 553-563. DOI: 10.20506/rst.6.3.307.

FELDE, O., KISS, K., BIKSI, I., JERZSELE, Á., and GYURANECZ， M. A., 2018. sertések Mycoplasma hyopneumoniae okozta tüdő gyulladása. (Pneumonia of 
pigs caused by Mycoplasma hyopneumoniae) Magy Állatorvosok Lapja. 140:337-348. URI: http://hdl.handle.net/10832/2680

FREUNDT, E. A. 1973. Principles of Mycoplasma classification. Ann. N.Y. Acad. Sci. 225: 713. PMID: 7287406.

GRAND, D. L., SARAS, E., BLOND, D., SOLSONA, M., and POUMARAT, F., 2004. Assessment of PCR for routine identification of species of the Mycoplasma mycoides cluster in ruminants. Vet. Res. 35: 635-649. DOI: 10.1051/vetres:2004037.

GROßHENNIG, S., TILL, I. J. G., BUSSE, J., FEUSSNER, I., and STULKE, J., 2016. Hydrogen sulfide is a novel potential virulence factor of Mycoplasma pneumoniae: characterization of the unusual cysteine desulfurase/desulfhydrase HapE Molecular Microbiology. 100(1): 42-54. PMID: 26711628. DOI: $10.1111 / \mathrm{mmi} .13300$.

HIROSE, K., KOBAYASHI, H., ITO, N., KAWASAKI, Y., ZAKO, M., KOTANI, K., OGAWA, H., and SATO, H., 2003. Isolation of mycoplasmas from nasal swabs of calves affected with respiratory diseases and antimicrobial susceptibility of their isolates. Journal of Veterinary Medicine B. 50:347-351. PMID: 14535934 DOI: 10.1046/j.1439-0450.2003.00681.x.

IKHELOA, J. O., AJUWAPE, A. T. P., and ADETOSOYE, A. I., 2004. Biochemical characterization and serological identification of mycoplasmas, isolated from pneumonic lungs of goats slaughtered in abattoirs in Northern Nigeria. Small Rumin. Res. 52:93-97. ISSN: 0921-4488.

KILIC, A., KALENDER, H., EROKSUZ, H., MUZ, A., and TASDEMIR, B., 2013. Identification by culture, PCR, and immunohistochemistry of mycoplasmas and their molecular typing in sheep and lamb lungs with pneumonia in Eastern Turkey Trop Anim Health Prod. 45:1525-1531. doi: 10.1007/s11250-013-0394-3.

MAKSIMOVIĆ, Z., CHRISTIAN, D. F. E., and MAID, R., 2013., Presence of mycoplasmas in the respiratory system of small ruminants managed under an extensive production system Turk J Vet Anim Sci. 37: 352-354. https://doi.org/10.3906/sag-1209-76.

MCAULIFFE, L., ELLIS, R. J., MILES, K., AYLING, R. D., and NICHOLAS, R. A., 2006. Biofilm formation by Mycoplasma species and its role in environmental persistence and survival. Microbiology. 152: 913-922. PMID: 16549656 DOI: 10.1099/mic.0.28604-0

NIANG, M., ROSENBUSCH, R. F., LOPEZ-VIRELLA, J., and KAEBERLE, M. L., 1999. Differential serologic response to Mycoplasma ovipneumoniae and Mycoplasma arginini in lambs affected with chronic respiratory disease. J Vet Diagn Invest. 11: 34-40. PMID: 9925209 DOI: 10.1177/104063879901100105.

NICHOLAS, R., AYLING, R., and MCAULIFFE, L., 2008. Contagious agalactia. In: Mycoplasma Diseases of Ruminants. CABI, Wallingford, UK, 98-113. ePDF 9781845934644

NICHOLAS, R. A.J. 2017. Mycoplasmology: the big issues Anim Husb Dairy Vet Sci. 1 (1): 1-4. DOI:10.15761/AHDVS.1000102.
OIE., 2017. OIE Terristerial Manual 2017. OIE Manual of Diagnostic Tests and Vaccines for Terrestrial Animals seventh Edition, 1(2): 1404.

PRITCHARD, R. E., and MITCHELL, F. B., 2015. Mycoplasma iowae: relationships among oxygen, virulence, and protection from oxidative stress Veterinary Research. 46:36. DOI: https://doi.org/10.1186/s13567-015-0170-7

SHATALIN, K., SHATALINA, A., MIRONOV, A., and NUDLER, E., 2011. $\mathrm{H}_{2} \mathrm{~S}$ : a universal defense against antibiotics in bacteria. Science. 334: 986-990. PMID: 22096201. DOI: $10.1126 /$ science. 1209855

TAMURA, K., STECHER, G., PETERSON, D., FILIPSKI, A., and KUMAR, S., 2013., MEGA6: Molecular Evolutionary Genetics Analysis version 6.0. Molecular Biology and Evolution. 30: 2725-2729. doi: 10.1093/molbev/mst197.

TERLAAK, E. A., NOORDERGRAAF， J. H., and VERSCHURE, M. H., 1993. Susceptibilities of Mycoplasma bovis, Mycoplasma dispar, and Ureaplasma diversum strains to antimicrobial agents in vitro. Antimicrob. Agents Chemother. 37: 317. DOI: 10.1128/AAC.37.2.317.

VAN KUPPEVELD, F. J., VAN DER LOGT, J. T. ANGULO, A. F., VAN ZOEST, M. J., QUINT, W. G., NIESTERS, H. G., GALAMA, J. M., and MELCHERS, W. J., 1993. Genus- and speciesspecific identification of mycoplasmas by $16 \mathrm{~S}$ rRNA amplification. Appl Environ Microbiol. 58(8):2606-15. doi: 10.1128/aem.58.8.2606-2615.1992. Erratum in: Appl Environ Microbiol. 1993 Feb. 59(2):655. PMID: 1381174; PMCID: PMC195828. PMID: 1381174 PMCID: PMC195828 DOI: 10.1128/aem.58.8.26062615.1992.

How to cite this article:

Mona, M. Osman; Manal Abu Elmakarem Mohamed; Heba N. Deif and Kamelia, M. Osman, 2021. Virulence traits and antimicrobial sensitivity testing of untyped Mycoplasma species recovered from sheep and goats in Egypt. Journal of Applied Veterinary Sciences, 6 (4): $39-45$.

DOI:https://dx.doi.org/10.21608/javs.2021.88356.1095 